\title{
Diffuse large B-cell lymphoma with chronic inflammation
}

INSERM

\section{Source}

INSERM. (1999). Orphanet: an online rare disease and orphan drug data base. Diffuse large B-cell lymphoma with chronic inflammation. ORPHA:300888

Diffuse large B-cell lymphoma with chronic inflammation is an Epstein-Barr virusassociated malignant lymphoproliferative disorder, developing in a context of longstanding or slow-growing, chronically inflamed lesions, such as chronic pyothorax, metallic implants in bones and joints, chronic osteomyelitis, chronic venous ulcer, or, rarely granulomatous inflammation. The tumor is usually primarily localized, with no involvement of other organs. 